\title{
Other articles noted
}

\section{Therapeutics}

Estrogen for Alzheimer's disease in women: randomized, double-blind,placebo-controlled trial. Henderson VW, PaganiniHill A, Miller BL, et al. Neurology 2000 Jan 25;54:295-301.

Treatment of attention-deficit/hyperactivity disorder. Jadad AR, Boyle M, Cunningham C, et al. Evidence Report/Technology Assessment no. 11. AHRQ publication no.00-E005. Rockville, MD: Agency for Healthcare Research and Quality. November 1999. http://www.ahcpr.gov/clinic/adhdsum.htm

Loxapine for schizophrenia. (Cochrane Review, latest version 27 Oct 1999). Murphy B, Fenton M, Wood J, et al. In: Cochrane Library. Oxford: Update Software.

A randomized controlled trial of cognitive-behavioral therapy for persistent symptoms in schizophrenia resistant to medication. Sensky T, Turkington D, Kingdon D, et al. Arch Gen Psychiatry $2000 \mathrm{Feb} ; \mathbf{5 7}: \mathbf{1 6 5}-72$.

Does exercise aid smoking cessation?: A systematic review. Ussher MH, Taylor AH, West R, et al. Addiction 2000 Feb;95:199_ 208.

Communities mobilizing for change on alcohol (CMCA): effects of a randomized trial on arrests and traffic crashes. Wagenaar AC, Murray DM, Toomey TL. Addiction 2000 Feb;95:209-17.

\section{Diagnosis}

A $37 \mathrm{kDa}$ 2-5A binding protein as a potential biochemical marker for chronic fatigue syndrome. De Meirleir K, Bisbal C, Campine I, et al. Am J Med 2000 Feb;108:99-105.

\section{Prognosis}

Mortality and causes of death in a total national sample of patients with affective disorders admitted for the first time between 1973 and 1993. Høyer EH, Mortensen PB, Olesen AV. Br J Psychiatry 2000 Jan;176:76-82.

\section{Aetiology}

Further evidence of relation between prenatal famine and major affective disorder. Brown AS, van Os J, Driessens C, et al. Am J Psychiatry $2000 \mathrm{Feb} ; \mathbf{1 5 7 : 1 9 0 - 5}$.

Does old age reduce the risk of anxiety and depression?: A review of epidemiological studies across the adult life span. Jorm AF. Psychol Med 2000 Jan;30:11-22.

Psychiatric illness and risk factors for suicide in Denmark. Mortensen PB, Agerbo E, Erikson T, et al. Lancet 2000 Jan 1;355:912.

Mortality and mental disorders in a Spanish elderly population Saz P, Launer LJ, Día JL, et al. Int J Geriatr Psychiatry 1999 Dec;14:1031-8.

\section{Qualitative}

Systematic review of the effect of on-site mental health professionals on the clinical behaviour of general practitioners. Bower P, Sibbald B. BMJ 2000 Mar 4;320:614-7. Review.

\section{EBMH feedback on the web}

We welcome letters from our readers about Evidence-Based Mental Health. Your feedback is most important in assisting us to produce a high quality journal which is useful to the practising mental health clinician. All letters will be put up on the web site; for the latest feedback please go to http://www.psychiatry.ox.ac.uk/cebmh/journal/letters.html

All letters should be typewritten, double spaced, and mailed or faxed to Angela Eady in the Canadian editorial office (Health Information Research Unit, Faculty of Health Sciences, McMaster University, HSC 3H7, Hamilton, Ontario L8N 3Z5, Canada. Fax +1905546 0401).

\section{How to cite Evidence-Based Mental Health}

CITATION OF MATERIAL FROM THE NOTEBOOK:

- Streiner D, Geddes J. Some useful concepts and terms used in articles about diagnosis [EBMH notebook]. Evidence-Based Mental Health 1998 Feb;1:6-7.

CITATION FOR MATERIAL TAKEN FROM A STRUCTURED ABSTRACT, WRITTEN WITHOUT ATTRIBUTION BY A STAFF MEMBER:

- Caregiver training delayed admission of patients with dementia to nursing homes [abstract]. Evidence-Based Mental Health 1998 Feb;1:9. Abstract of: Brodaty H, Gresham M, Luscombe G. The Prince Henry Hospital dementia caregivers' training programme. Int J Geriatr Psychiatry 1997 Feb;12:183-92.

CITATION FOR MATERIAL TAKEN FROM A COMMENTARY TO AN ARTICLE:

- Bradley C. Commentary on "Purchase of a handgun was associated with an increased risk of suicide or death by homicide." Evidence-Based Mental Health 1998 Feb;1:28. Comment on: Cummings P, Koepsell TD, Grossman DC, et al. The association between the purchase of a handgun and homicide or suicide. Am J Public Health 1997 Jun;87:974-8. 